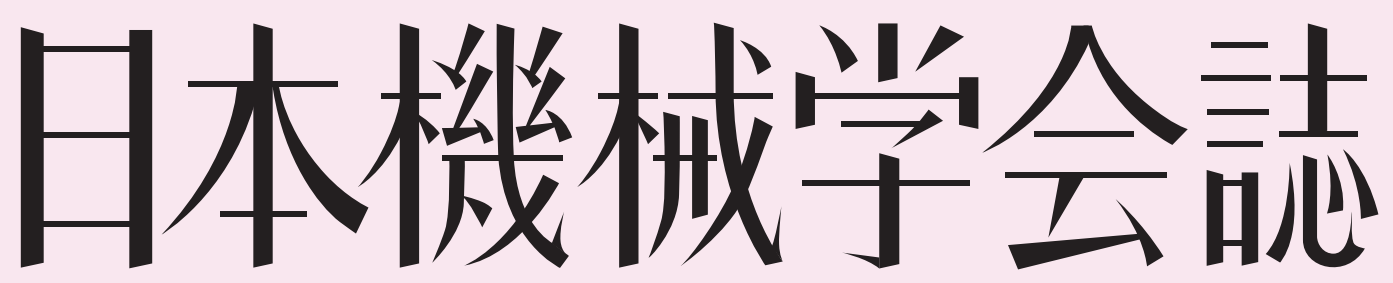

CONTENTS

特集 スポーツ×ICT

4 NECのスポーツ・イベントにおける ICT 活用の取り組み

横山 登[日本電気(株) $]$

8 体操採点システム

本田 崇・栘井 昇一〔(株) 富士通研究所〕・佐々木 和雄〔富士通(株)〕

13 浮遊球体ドローンディスプレイ

山田 渉〔(株)NTTドコモ〕

16 東京オリ・パラに関連した競技自転車ウェアの開発

浅井武·黒澤 佑太·洪性賛(筑波大学)

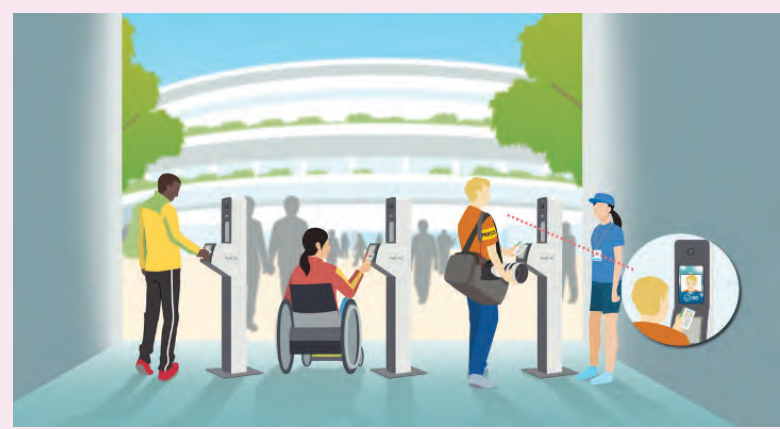

東京 2020 大会に納入する顔認証システム利用時のイメージ

『NEC におけるスポーツ・イベントにおける ICT 活用の取り組み』より

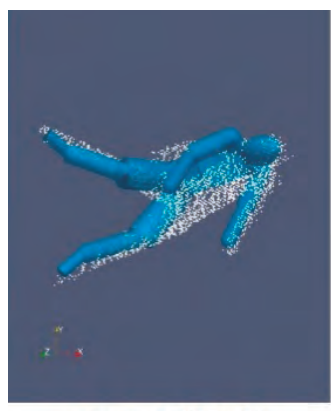

フィッティング初期值 (故意によるずらしあり)

鞍馬演技のフィッティング例

『体操採点システム』より

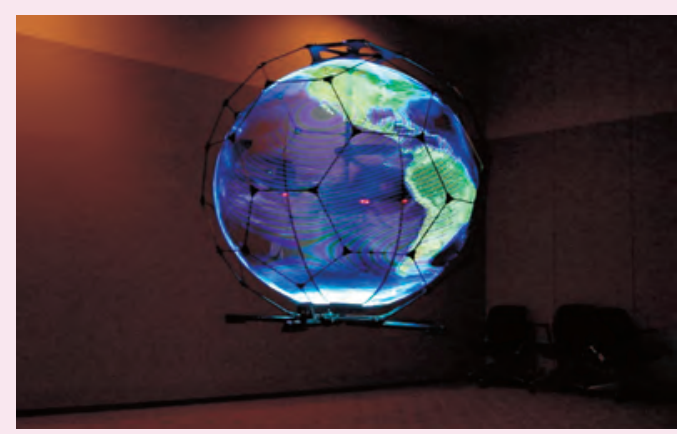

飛行中の浮遊球体ドローンディスプレイ 『浮遊球体ドローンディスプレイ』より

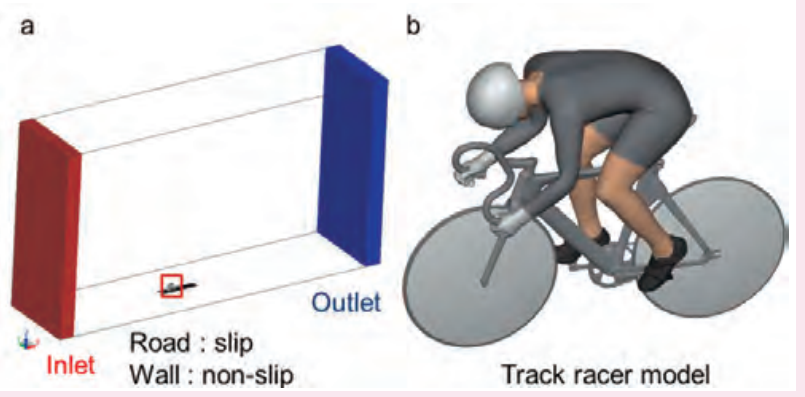

Schemata of simulation area (a) and Track racer model (b) 『東京オリ・パラに関連した競技自転車ウェアの開発』より 


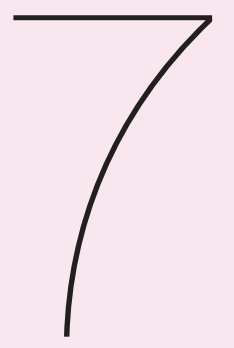

20 鞿械工学年鑑発行のお知らせ

30 やさしい熱力学

第 7 回 可逆サイクル

32 2020年度年次大会 颜ろう名古屋で

34 令と和の産学連携

日本の産学連携の課題はどこにあるか?

『産学官連携ジャーナル』編集長に聞く

36 Tips for Academic Publishing アクセプトに繋げる論文投稿 \& 学術出版の豆知識 第 7 回 Common reasons for manuscript rejection and what you can do to avoid these 論文がリジェクトされる 10 の理由

38 統計で読む" 経済・産業の動き"

第 7 回 日本経済の歩み(2)

ーニクソンショック以降プラザ合意までー

40 羭文アクセスランキング

日本機械学会学術誌(和文) 年間アクセス数トップ 10

42 研究ストーリー

「伸張レオメーター」の上にも 15 年

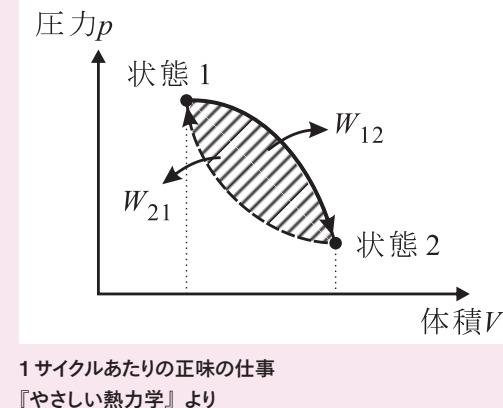

『やさしい熱力学』より

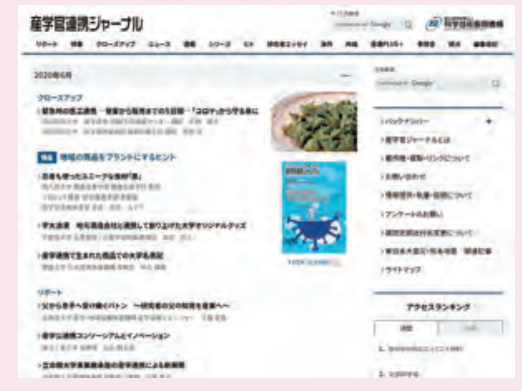

2020 年 7 月にリニューアルされる産学官連携ジャーナル Webサイト

『令と和の産学連携』より

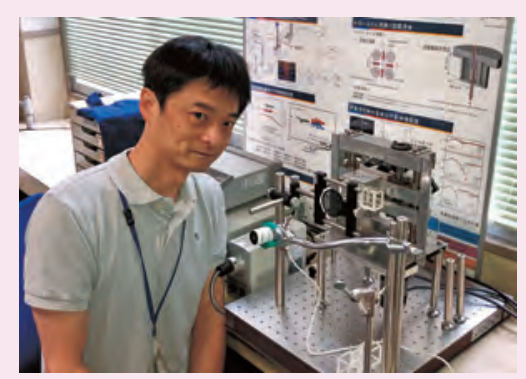

津山工業高等専門学校 総合理工学科 准教授 加藤学氏 『研究ストーリー』より

\section{JSME アクティビティ}

オンライン開催イベント案内 /ROBOMECH2020 開催報告 / イベントー覧 / フェロー適任者推薦のお願い / 学会賞等募集要項 / 求人公募 / 次号予定 / 編集後記 / 理事会議事録 